DOI: $10.1515 /$ rpp-2017-0047

Doctor of Pedagogical Sciences, Full Professor, OLENA HOMONYUK

Khmelnytskyi National University

Address: 11 Instytutska St., Khmelnytskyi, 29016, Ukraine

E-mail: elena_gomonyuk29@ukr.net

Postgraduate Student, NATALIA AVRAMENKO

Khmelnytskyi National University

Address: 11 Instytutska St., Khmelnytskyi, 29016, Ukraine

E-mail: edelnata@yahoo.de

\title{
FOREIGN EXPERIENCE IN MASTERING MEDICAL PROFESSIONAL TERMINOLOGY BY FOREIGN STUDENTS AT MEDICAL UNIVERSITIES
}

\begin{abstract}
Professional broadcasting of future medical foreign workers in the medical sector is a compulsory component of their professional readiness. The diversity of professional broadcasting functions of foreign students, the skillful use of the entire range of speech functionality, its external expressive attributability of speech; these are the most important means of medical skills, which are achieved by training at preparatory faculties. The purpose, principles, approaches, content and structure of the program that realize the concept of Ukrainian-language training of foreign citizens in Ukrainian universities have been described. Comparative analysis of the curriculum on studying Ukrainian, Russian languages by foreign students in CIS countries has been conducted. It has been shown that the program meets the requirements of the General Education Standards in the Ukrainian language as a foreign language, the All-European Recommendations on Language Education and defines the levels of language and communicative competence of foreign students for the main types of speech activity: speaking, listening, reading and writing. The program provides the students with communicative needs in everyday life, educational, professional, socio-cultural, educational and scientific spheres and the formation of a communicative competence that will contribute to the formation of the linguistic personality of a future specialist. The analysis of professional broadcasting of future foreign medical workers as a socio-pedagogical problem has been carried out. The importance of mastering professional speech as an obligatory part of professional readiness of foreign students-physicians has been singled out. The efficiency of the methodical system for implementation pedagogical conditions in the process of studying at preparatory faculties in medical universities has been analyzed. All material has been tailored to meet the goals and objectives defined by the cognitive and professional needs of foreign students.

Keywords: preparatory department, foreign students, curriculum, Ukrainian as a foreign language.

\section{INTRODUCTION}

The problem of training of the Ukrainian-language to foreign citizens of nonphilological universities requires from the lecturers of humanitarian departments the comprehension of the latest trends in multicultural education and the ability to form students' language skills in preparing for their future profession. The training of foreign
\end{abstract}


students-future doctors in Ukraine has a certain specificity, which is connected with the entry of a foreigner into the Ukrainian socio-cultural space and the emergence of such a problem as a language barrier.

\section{THE AIM OF THE STUDY}

The aim of the study is to analyze and compare the training of foreign students in the preparatory department at medical universities in the CIS countries.

\section{THEORETICAL FRAMEWORK AND RESEARCH METHODS}

The principles of the scientific theory of cognition about the unity of language, speech, thinking, the relationship of sensual and rational in teaching, as well as the principle of professional orientation of training for foreign students at preparatory faculties in medical universities became the theoretical and methodological basis of the study.

The analysis of scientific literature showed that J. Cherkashina, V. Gumenyuk, I. Kozubovskaya, T. Shmonin and others studied the problem of professional training of foreign citizens in Ukraine. In Ukraine and beyond, attempts have been made to conclude curricula in the Ukrainian language for the initial stage of its study (L. Antonov, M. Dudka, O. Gudzenko, L. Novitska, L. Sergiychuk, B. Sokil, N. Stankevich and etc.). Among the foreign authors, the problems of pre-university training have studied: G. Aksenova, V. Belyi, A. Melecinek, G. Mukhametzanova, S. Pudlovsky, R. Kuatbekova et al.

In order to solve the settled tasks and realization of the aim of the study, a set of interrelated theoretical research methods was used, namely: theoretical analysis, comparison and synthesis of scientific sources, textbooks and curricula of the investigative problem in order to select and understand the actual material. The comparison, generalization, systematization and synthesis of the obtained data for the analysis of scientific and methodical literature have been carried out.

\section{RESULTS}

An important condition for the successful functioning and development of the system of preparatory education for foreign citizens is the development of methodology, theory and practice of harmonization of all its levels and degrees, including the subsystems of additional pre-university training. It is primary in relation to other educational degrees. An analysis of the experience of foreign countries shows that in many of them there is no such agreement between educational levels at all. This is due to many factors, and mainly the difference in socio-economic, socio-cultural, national-historical conditions of development of countries.

Developed European countries have a high level of education, educational degrees and standards. In countries such as Jordan, Palestine, Egypt, Cameroon, Nigeria, Angola, Ecuador, and others whose students come to study at medical universities in Ukraine, the level of education is lower, pre-university training does not meet the requirements of higher education institutions in developed countries, in particular Ukraine. Given the urgent needs for high-skilled professionals, the above-mentioned countries face great difficulties when they are sending young people to study at universities in other countries because of inconsistencies in educational levels (Antoniv, Sokol \& Stankevich, 2004, p. 85).

The reception of foreign citizens of high-level education is complicated by weak basic natural, linguistic, humanitarian training and their lack of professional orientation. This significantly complicates the acquisition of their knowledge in the Ukrainian language as a foreign language, the acquisition of professional terminology, adaptation to the educational process of universities and, in general, socioeconomic, socio-cultural conditions of the host country. 
Students from Africa, the Far and Middle East, Western and Central Europe are experiencing significant difficulties in communicating during the first weeks, months of their stay in Ukraine. Given the fact that these are the students from African and Arabian countries that constitute the overwhelming majority at some universities, the language problem remains pressing and needs to be solved. (Trostynska \& Ushakova, 2009, p. 45).

Thus, the free study of the Ukrainian (Russian) language of such different nationalities, such as: Arabs with their rapid mastering of conversational language and Chinese, who for the best memorization rely on the letter knowledge, at the initial stage of studying the language is difficult and incomprehensible. Arab students usually seek to overcome quickly the language barrier to adapt easily to a new reality. Already at the first language lessons, they demonstrate activity, ease in the assimilation of a new language, the desire to achieve fast results.

The preparatory department is a unique structural subdivision of one of the oldest medical universities in Ukraine - Vinnitsa National Medical University, which rightfully bears the name of the great Pirogov, whose ideas, practical experience are of great importance for modern medicine.

The preparatory department is created specifically to solve all the initial problems of a foreign student and, above all, the problem of language and communication. The system of individual classes, consultations is foreseen. Lecturers prepare students for classes on the first year, taking into account the basic knowledge gained at educational institutions of different levels in different countries of the world.

Language learning begins from the first minutes of their stay in the country. A clear system of educational process is created, the purpose of which is to teach how to communicate with Ukrainians and to receive highly-qualified education with students from the preparatory faculty from Europe, Asia, Africa and Latin America to maintain the profession of physician.

At the same time together with inorganic communication and educational work, the research work of the department was started: the problems of adaptation of foreign citizens to life and study under the conditions of a new social environment are studied; the questions of language preparation of students of the preparatory faculty for foreign citizens are being developed in order to master the general subjects and to study at the senior courses of medical university. Much attention is paid to the coordination of the work of teachers, broadcasters and teachers of the natural sciences.

Also, the teachers theoretically grounded and created a system for monitoring the level of formation of language knowledge, skills and abilities of the students of preparatory faculty for foreign citizens.

Foreign citizens study both Ukrainian and Russian languages as foreign at the preparatory department at Vinnitsa Medical University named after M. Pirogov. The study of Ukrainian and Russian languages is planned for 238 hours according to the curriculum. During the academic year, students study Ukrainian, Russian for 6-8 hours a week. Also, the curriculum provides two content modules per year. In the first year 136 hours includes 1 module and 102 hours module 2, as well as 46 hours of homework.

In connection with the introduction of the course "Ukrainian as a Foreign Language" and in order to provide the educational process with methodological materials, several groups of lecturers published manuals and textbooks based on fiction and scientific literature of the Ukrainian and Russian languages "The country in which I am studying", "Study grammar in the Ukrainian language", the textbook on the Ukrainian language, the 
initial level "Introductory Phonetic-grammar course", the manual "Let's Go Together" (the initial level of studying the Ukrainian language as foreign terrestrial), a teaching manual on the Russian language for foreign students "Organization of the health care system in Ukraine" (Mazuryk, 2006, p. 111).

Teaching foreigners medicine, dentistry and pharmacy at Lviv National Medical University named after D. Galytsky is carried out in three languages in Ukrainian, English or Russian. Teaching English was introduced in 1997. Today, 953 students $(88,4 \%$ of the total number of foreign students) study in English. In addition to language training, students in the preparatory department have the opportunity to improve their basic education in biology, chemistry and physics.

The content of the curriculum program "Ukrainian as a Foreign Language" is structured into three concentrators that correspond to three levels of proficiency in the Ukrainian language. Contents of the educational material Concentration 1 corresponds to the first A 1 - Primary level (Elementary) and is calculated, respectively, for 150 practical and 70 hours of independent work of students. Concentration 2 is a training content that corresponds to level A 2 - Basic (Pre-Threshold) and is designed for 300 practical and 130 independent hours of study. Concentration 1 and Concentrator 2 correspond to the first semester of the preparatory faculty.

Concentration 3 corresponds to the level B 1 - I to the average level (Threshold) and is calculated on 270 practical and 160 academic hours of independent work of students, which is realized during the second semester of the preparatory faculty (Nikolaev, 2003, p. 35).

The Kharkiv National Medical University teaches in two languages: English and Russian. Accordingly, curricula and programs have been created taking into account all levels, directions and objectives of education.

Innovations of the Kharkov National Medical University have been created in 2009 special courses for foreign students. The system of corrective special courses helps to determine the basic level of training, the ability of students to learn in general, improve their language level, etc.

Studying foreign students in other CIS countries is somewhat different. For example, at the Belarusian State Medical University, at the preparatory department, foreigners are trained in a volume of 900 hours of Russian or Belarusian languages. Russian, (Belarusian) language as a foreign language is taught for foreign citizens at the preuniversity stage and for 1-3 courses of the medical faculty for foreign students.

Pre-university training at the University is carried out at the Faculty of Professional guidance and Pre-University Preparation. A distinctive feature of the faculty in comparison with other medical universities of Belarus is an organic combination of training of native and foreign students. In Vitebsk, Grodno and Gomel medical universities, preparation for the first year of foreign citizens is held at the faculties of foreign entrants. (Aksenova, 2011, p. 25).

The preparatory department is a structural subdivision of the university. In the last years of the existence of an educational institution there are three forms of education: fulltime, part-time, evening. The daytime study is traditionally considered the most effective.

During the academic year students study 36 hours a week the subjects of entrance examinations (biology, chemistry, Russian or Belarusian language).

Of great importance, teachers pay attention to the language training of foreign citizens, without which it is impossible to provide proper vocational education. The educational process uses the latest achievements of pedagogical design: modern author 
language textbooks (along with CD), provided with narrative support, interactive and multimedia educational teaching technologies; author's computer programs: demonstration, educational; virtual laboratory works of Russian and Belarusian as foreign languages; language simulators, etc.

Pre-university preparation of foreign students is an important mean for enrollment of entrants for the first year of medical faculty of foreign students. In the current academic year, 144 foreign students were admitted to study. Students of the faculty were citizens from far abroad (USA, Portugal, Germany, Tunisia, Mongolia).

In the next academic year, the preservation of the recruitment of foreign citizens, the diversification of their reception and accentuation of attention on improving the quality of training and improvement of the material and technical basis of education is planned (Belyi, 2010, p. 10).

In the Kyrgyz State Medical Academy named after I. Akhunbayev pre-university training of foreign students occupies a special place in the educational process. The preparatory department at the Academy exists for over 75 years. The main task of the preparatory courses is to train students from the countries of the near and far abroad before joining the KSMA. Classes at the preparatory faculty are held in Russian and Kyrgyz languages. Foreign students also attend courses of studying Russian and Kyrgyz languages. Teachers know foreign languages excellent, which allows them to contact the students from the first days of study.

The curriculum for preparatory courses for foreign citizens in KSMA includes:

- full course of Russian language (9 months) and profile subjects (biology, chemistry -6 months)

- a special course of the Russian language (6 months) for foreign citizens without the preparation of profiling subjects (Ivanyshyn, 2016, p. 163).

The work is based on the use of the latest interactive teaching methods.

In the Kyrgyz State Medical Academy. I. Akhunbayeva the training of foreign students from different countries, until 2001, was conducted in Russian.

In 2001, the Center for Compulsory Education established a department with partial English language training for students from foreign countries who speaks English.

The development of curricula and syllabuses has taken into account the experience of the work of KSMA with foreigners, recommendations of the experts of the World Health Organization (WHO). As a result, it was decided to use the WHO pilot curriculum with some additions that take into account the specifics of teaching.

For the students of the department a computer class was prepared, with the necessary software for working on such disciplines as English and Russian languages, computer science.

The purpose of the faculty's establishment for foreign citizens is to train qualified specialists in the specialty "Doctor - Medical Advisor" who speaks English to continue their professional activities in foreign countries (Zluktenko, 2001, p. 203).

Experienced teachers from other universities (of physics, Russian, English, history of medicine, sociology) were involved in teaching disciplines. Further intensive English language courses for teachers of KSMA were organized; lecturers from English-speaking countries were invited.

For the students of the department computer classes with the necessary software for working on such disciplines as English and Russian languages, computer sciences were prepared. The most difficult problem was the provision of students with teaching aids in English. 
The main tasks of the faculty for foreign citizens are:

1. Satisfaction of the society needs in qualified medical staff with higher education, who fluently speaks English;

2. Preparation of professorial teaching staff, proficiency in English;

3. Development of exports of medical education; dissemination of knowledge among the population, raising its general level of education;

4. Accumulation, preservation and increase of ethical, scientific and cultural values of society in the medical science field;

5. Attraction of additional funds for the development of medical education and medical science (Bilaiev, 2007, p. 102).

In the State Medical University of Semey (Kazakhstan), the preparatory department was established in 1995. Foreign students study Russian language as well as relevant subjects before taking exams. For the first time, 43 foreign students from India, Pakistan, Palestine, Syria and Jordan were enrolled at the university for studying in different specialties in the Russian language teaching unit.

In 1998, the university signed an agreement with TECAS International, on admission of foreign nationals, for studying in different specialties, where teaching is conducted in English.

Thanks to the signing of the agreement and the joint efforts of the University and TECAS International, the State Medical University of Semei became the first state medical university in Central Asia, where, in addition to the Russian and Kazakh languages, students have the opportunity to study in English. The university developed syllabuses of disciplines in English (Kuatbekova, 2016, p. 47).

This is one of the main reasons why a large number of foreign students wish to enter this university. The preparatory section for foreign students functions in the separation of foreign students, where, in addition to study of the Russian language, they are trained in the subjects for the preparation entrance examinations.

\section{CONCLUSIONS}

Thus, the study of the Ukrainian language as a foreign language at the preparatory faculties of medical universities makes it possible to implement the main provisions of the Concept of language training of foreign citizens in higher educational institutions of Ukraine.

The course of the Ukrainian language as a foreign language in diverse higher education institutions should facilitate the training of professionals of the appropriate professional and intellectual level, for which language education should become a compulsory component of vocational training.

The basics of professional broadcasting of future medical foreign workers should be laid out while studying Ukrainian as a foreign language at preparatory faculties in higher educational institutions.

The problem of professional broadcasting formation of future foreign specialists at the preparatory faculties at the high school is not sufficiently studied; there is a contradiction between the modern requirements of the society to the system of medical education and the level of vocational training of students.

The main tasks of teaching Ukrainian as a foreign language at preparatory faculties are as follows:

- to form in communicative-language, linguistic, discursive, socio-cultural and active competences of foreign students;

- to teach students to use communicatively the various means of the Ukrainian language and to use foreign language communication on the basis of the practical mastering 
of the basic linguistic and linguistic concepts, norms of the Ukrainian literary language, culture of communication;

- to create and develop a positive motivation for the educational activities of foreign students and to intensify cognitive interests, to develop creative abilities;

- to form the spiritual world, integral ideological representations, universal human reference points and to raise respect for the country whose language is being studied.

Prospects for further exploration we see in the creation and testing of a training and methodical complex for foreign students preparatory department of medical universities.

\section{REFERENCES}

1. Aksenova, G. N. (2010). Zivem i uchimsya v Belarusii. Minsk: BGMU.

2. Antoniv, L. V., Sokol, B. M., \& Stankevich, N. I. (2004). Prohrama z ukrainskoyi movy dlia studentiv-inozemtsiv vyshchykh navchalnykh zakladiv. Lviv: Publisher LNU.

3. Belyi, V. V. (2010). Krasa belorusskogo kraja. Minsk: BGMU.

4. Bilaiev, O. M. (2007). Metodyka vyvchennia ukrainskoi movy. Kyiv: Ukrainska entsyklopedia.

5. Ivanyshyn, H. (2016) Typova programma z ukrainskoi movy yak inozemnoi dlia pidhotovchuch fakultetiv vyschuch navchalnych zakladiv Ukrainy: teoriia i praktyka ukladannia. Naukovi zapysky. Seriia: Pedahohika. 4, 163-169.

6. Kuatbekova, R. A., Akkuzov, A. A., Kuatbekov, N. A., \& Kajyrbekova, U. S. (2016). Obuchenie terminologii specialnosti kak uslovie formirovania professionalnoi kommunikativnoi kompetencii studentov-medikov. Nayka i mir, 9 (37), 47-50.

7. Mazuryk, D. (2006). Sposoby vyznachennya rivnya volodinnya ukrayins'koyu movoyu yak inozemnoyu. Visnyk Lvivskoho universytety. Seriia: Filolohia, 38, 111-115.

8. Nikolaev, S. Yu. (2003). Zahalnoievropeiski Rekomendatsii z movnoi osvity: vyvchennia, vykladannia, otsiniuvannia. Kyiv: Lenvit.

9. Trostynska, O. M., \& Ushakova, N. I. (2009). Yedyna typova navchalna prohrama z ukrainskoi movy dlia studentiv-inozemtsiv osnovnykh fakultetiv nefilolohichnoho profiliu vyshchykh navchalnykh zakladiv Ukrayiny III-IV rivniv akredytatsii. Kyiv: NTUU "KPI".

10. Zluktenko, Yu. O. (2001). Metodyka vykladannia inozemnykh mov u vyshchii shkoli. Kyiv: Vyscha schkola. 